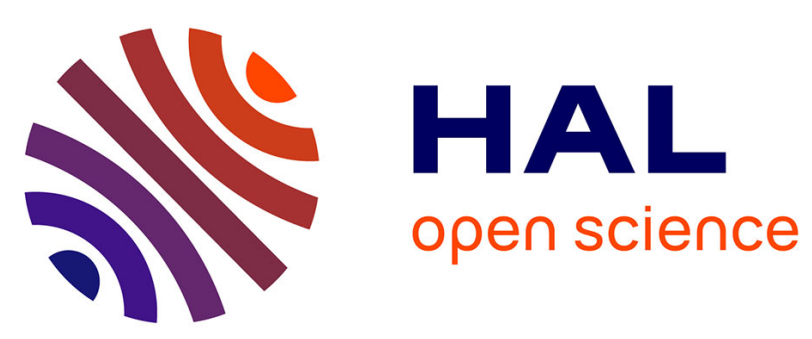

\title{
A molecular and isotopic study of the organic matter from the Paris Basin, France
}

Eric Lichtfouse, Pierre Albrecht, Françoise Béhar, John M. Hayes

\section{To cite this version:}

Eric Lichtfouse, Pierre Albrecht, Françoise Béhar, John M. Hayes. A molecular and isotopic study of the organic matter from the Paris Basin, France. Geochimica et Cosmochimica Acta, 1994, 58 (1), pp.209-221. 10.1016/0016-7037(94)90458-8 . hal-00191892

\section{HAL Id: hal-00191892 \\ https://hal.science/hal-00191892}

Submitted on 29 Nov 2007

HAL is a multi-disciplinary open access archive for the deposit and dissemination of scientific research documents, whether they are published or not. The documents may come from teaching and research institutions in France or abroad, or from public or private research centers.
L'archive ouverte pluridisciplinaire HAL, est destinée au dépôt et à la diffusion de documents scientifiques de niveau recherche, publiés ou non, émanant des établissements d'enseignement et de recherche français ou étrangers, des laboratoires publics ou privés. 
Revised version

Geochimica et Cosmochimica Acta 58, 209-221, 1994.

doi:10.1016/0016-7037(94)90458-8

Correspondence: Dr. Eric Lichtfouse, INRA-CMSE-PME, 17, rue Sully, 21000 Dijon, France

Eric.Lichtfouse@dijon.inra.fr

\title{
A molecular and isotopic study of the organic matter from the Paris Basin, France *
}

\author{
Eric LICHTFOUSE ${ }^{1 \#}$, Pierre ALBRECHT ${ }^{2}$, Françoise BÉHAR ${ }^{3}$ and John M. HAYES ${ }^{4}$
}

\author{
${ }^{1}$ Université Pierre et Marie Curie, Laboratoire de biogéochimie isotopique, \\ associé à l'Institut National de la Recherche Agronomique, 75252 Paris Cedex 05, France. \\ ${ }^{2}$ Institut de Chimie, Université Louis Pasteur, 67000 Strasbourg, France. \\ 3 Institut Français du Pétrole, 92500 Rueil-Malmaison, France. \\ ${ }^{4}$ Biogeochemical laboratories, Indiana University, Bloomington, IN 47405, U.S.A.
}

\section{ABSTRACT}

Thirteen Liassic sedimentary rocks of increasing depth and three petroleums from the Paris Basin were studied for ${ }^{13} \mathrm{C} /{ }^{12} \mathrm{C}$ isotopic compositions and biological markers, including steranes, sterenes, methylphenanthrenes, methylanthracene and triaromatic steroids. The isotopic compositions of $n$-alkanes from mature sedimentary rocks and petroleums fall in a narrow range $(2 \%$ ) except for the deepest Hettangian rock and the Trias petroleum for which the short-chain $n$-alkanes are enriched and depleted in ${ }^{13} \mathrm{C}$, respectively. Most of the molecular parameters increase over the $2000-2500 \mathrm{~m}$ depth range, reflecting the transformation of the organic matter at the onset of petroleum generation. In this zone, carbonate content and carbon isotopic composition of carbonates as well as molecular parameters are distinct for the Toarcian and Hettangian source rocks and suggest a migration of organic matter from these two formations. Two novel molecular parameters were defined for this task, one using methyltriaromatic steroids from organic extracts and the other using 1-methylphenanthrene and 2-methylanthracene from kerogen pyrolysates. The anomalous high maturity of the Dogger petroleum relative to the maturity-depth trend of the source rocks is used to estimate the minimal vertical distance of migration of the organic matter from the source rock to the reservoir.

\section{INTRODUCTION}

Molecular fossils have been increasingly used to study the nature and transformation of sedimentary organic matter, and are one of the best tools for the correlation of petroleum to source rocks (Welte et al., 1975, Leythaeuser et al., 1977, Seifert, 1978, Seifert and Moldowan, 1981, Peters and Moldowan, 1993). The chemical composition of the organic matter depends on source input, maturation, mineral catalysis, migration and biodegradation, making it necessary to use several and preferably independent parameters to analyse these transformations (Tissot and Welte, 1984). For example, the use of carbon isotopic compositions in addition to molecular parameters has been found useful to correlate various petroleums (Williams, 1974, Koons et al., 1974, Seifert and Moldowan, 1978).

The organic matter within Toarcian shales from the Paris Basin, mainly of type-II "marine", undergoes a notable transformation starting below $1500 \mathrm{~m}$ depth, the upper limit of the catagenic stage (Tissot et al., 1971, 1974, Ensminger et al., 1977, Mackenzie et al., 1980a, 1980b, 1981). The main source rocks are the Toarcian and Hettangian sedimentary rocks from the Lias formation. An important hydrocarbon depletion has been observed in the Hettangian source rocks : the Transformation Ratio TR, calculated by Rock-Eval pyrolysis, reaches $80 \%$ at the maximum subsidence of this formation indicating that it is an important contributing source of petroleum (Espitalié et al., 1987, 1988). However, correlating the pathways of petroleum migration is difficult because the mature source rocks and petroleums are undistinguishable using common molecular parameters, such as $n$-alkane distributions (I.F.P., unpublished data). In recent communications, we pointed out the possible discrimination between Toarcian and

\footnotetext{
* presented at the 3rd Latin American Congress on Organic Geochemistry, Manaus, Brazil, 1992.

\# to whom correspondance should be addressed.
} 
Hettangian source rocks using a novel molecular parameter based on triaromatic steroids (Lichtfouse et al., 1989, 1990). In this report we present a comparative study of these source rocks and neighbouring petroleums using several molecular parameters from organic extracts and kerogens together with the carbon isotopic compositions of carbonates and $n$-alkanes.

\section{EXPERIMENTAL}

\section{Geological setting}

Thirteen sedimentary rocks of increasing depth from various cores were chosen in the two organic richest formations of the Lias of the Paris Basin, the Toarcian shale and Hettangian marl layers (Table 1). The sedimentary rocks which have experienced enough thermal stress to generate petroleum are located in the central portion of the basin at a burial depth greater than $1500 \mathrm{~m}$ (Tissot et al., 1971). This depth limit represents the beginning of catagenesis and entrance into the main zone of petroleum generation. The Hettangian sedimentary rock located at the deepest part of this basin $(2700 \mathrm{~m})$ is the most mature rock. The Dogger, Domerian and Trias petroleums are also located in the center of the basin. For more detailed geological and geochemical information see Espitalié et al. (1987, 1988), Tissot et al. (1971).

\begin{tabular}{|cllcccccccc|}
\hline $\begin{array}{c}\text { DEPTH } \\
(\mathrm{m})\end{array}$ & NATURE & GEOLOGICAL & $\begin{array}{c}\text { SR } \\
(\%)\end{array}$ & $\begin{array}{c}\text { DIA } \\
(\%)\end{array}$ & $\begin{array}{c}\text { BA } \\
(\%)\end{array}$ & MPI3 & MPI3 $^{*}$ & MPA $^{*}$ & $\begin{array}{c}\text { SL } \\
(\%)\end{array}$ & $\begin{array}{c}\text { MTS } \\
(\%)\end{array}$ \\
\hline 810 & Rock & Toarcian & 25 & 47 & 19 & 0.95 & 0.76 & 0.97 & 50 & 19 \\
1030 & Rock & Toarcian & 22 & 66 & 14 & n.d. & 0.63 & 0.76 & 32 & 27 \\
1075 & Rock & Hettangian & 18 & 71 & 8 & 0.92 & 0.74 & 0.85 & 43 & 29 \\
1325 & Rock & Hettangian & 31 & 58 & 13 & 0.72 & 0.72 & 0.94 & 30 & 25 \\
2030 & Rock & Toarcian & 39 & 75 & 26 & 0.90 & 0.81 & 1.28 & 29 & 26 \\
2105 & Rock & Toarcian & 49 & 77 & 48 & 0.74 & 0.86 & 1.71 & 45 & 34 \\
2110 & Rock & Toarcian & 45 & 76 & 33 & 0.64 & 0.79 & 1.46 & 38 & 33 \\
2243 & Rock & Hettangian & 44 & 87 & 46 & 0.79 & 0.87 & 3.12 & 79 & 43 \\
2253 & Rock & Toarcian & 53 & 82 & 56 & 0.76 & 0.86 & 1.74 & 52 & 31 \\
2298 & Rock & Toarcian & 51 & 72 & 49 & 0.73 & 0.84 & 1.64 & 47 & 34 \\
2326 & Rock & Hettangian & 37 & 88 & 47 & 0.77 & 1.02 & 2.71 & 77 & 48 \\
2371 & Rock & Toarcian & 48 & 85 & 50 & 0.73 & 0.90 & 2.03 & 64 & 34 \\
2700 & Rock & Hettangian & 50 & 84 & 59 & 0.76 & 1.14 & 5.44 & 63 & 55 \\
1858 & Petroleum & Dogger & 54 & 85 & 66 & 0.77 & & & 61 & 39 \\
2200 & Petroleum & Trias & 43 & 90 & 61 & 0.69 & & & 74 & 37 \\
2435 & Petroleum & Domerian & 56 & 89 & 65 & 0.73 & & & 63 & 39 \\
\hline
\end{tabular}

Table 1. Geological characteristics and molecular parameters of organic-rich sedimentary rocks and petroleums from various cores of the Paris Basin. The steranes parameters SR, DIA, BA, were measured by gas chromatography-mass spectrometry monitoring the highly specific $372 \rightarrow 217$ transition. Other parameters were measured by gas chromatography-mass spectrometry using reconstructed ion currents: $m / z=192$ (MPI3, MPA), $\mathrm{m} / \mathrm{z}=231(\mathrm{SL})$ and $\mathrm{m} / \mathrm{z}=245(\mathrm{MTS}) . \mathrm{SR}=100 \times \alpha \alpha \mathrm{S} /(\alpha \alpha \mathrm{S}+\alpha \alpha \mathrm{R})\left(\mathrm{C}_{27}\right) . \mathrm{DIA}=\beta \alpha \mathrm{S} \times 100 /(\beta \alpha \mathrm{S}+\alpha \alpha \mathrm{S})\left(\mathrm{C}_{27}\right)$. $\mathrm{BA}=100 \times \beta \beta R /(\beta \beta R+\alpha \alpha \mathrm{R})\left(\mathrm{C}_{27}\right) . \mathrm{MPI} 3=(2-\mathrm{MP}+3-\mathrm{MP}) /(1-\mathrm{MP}+4-\mathrm{MP}+9-\mathrm{MP}) . \mathrm{MPA}=2-\mathrm{MP} / 2-\mathrm{MA} . \mathrm{SL}=100$ $\times \mathrm{C}_{20} /\left(\mathrm{C}_{20}+\mathrm{C}_{26} \mathrm{~S}\right) . \mathrm{MTS}=100 \times\left(2-\mathrm{C}_{21}+3-\mathrm{C}_{21}\right) /\left(2-\mathrm{C}_{21}+3-\mathrm{C}_{21}+4-\mathrm{C}_{21}\right) \cdot{ }^{*}:$ parameters from kerogen pyrolysates. n.d.: not determined. 


\section{Organic matter fractionation (scheme)}

Detailed extraction and fractionation procedures are described elsewhere (Lichtfouse, 1990). Freeze-dried cuttings were finely grounded and extracted three times with toluenemethanol $(3: 1 \mathrm{v} / \mathrm{v})$ at $40^{\circ} \mathrm{C}$. Kerogen concentrates, obtained by $\mathrm{HF}-\mathrm{HCl}$ treatment of the extracted rocks (Robinson, 1969), were pyrolysed under argon in open gold tubes at $600^{\circ} \mathrm{C}$ (Béhar et al., 1989). The extracts, petroleums or pyrolysates were fractionated into neutral and acid fractions by column chromatography on $\mathrm{KOH}$ impregnated silica gel (Mc Carthy and Duthie, 1962). The neutral fraction was then fractionated by thin layer chromatography (silica gel, methylene chloride) with friedelin and lupeol as references, to give a fraction enriched in hydrocarbons $\left(\mathrm{R}_{\mathrm{F}}>\sim 0.7\right)$ and an alcohol-ketone fraction $\left(\mathrm{R}_{\mathrm{F}} \sim 0.2-0.7\right)$. The hydrocarbon fraction was fractionated by thin layer chromatography (silica gel, $n$-hexane) with lup-20(29)ene, 1-ethylnaphthalene, 1-methylphenanthrene and 1,2:5,6-dibenzanthracene as references to give an alkane-alkene fraction and a triaromatic fraction. The alkane-alkene fraction was further fractionated by thin layer chromatography on $\mathrm{AgNO}_{3}$ impregnated silica gel ( $n$-hexane) to give separate alkane and alkene fractions. $n$-Alkanes were removed from the alkane fraction by adsorption on $5 \AA$ molecular sieves to give a branched-cyclic alkane fraction ( $\mathrm{O}^{\prime}$ Connor et al., 1962).

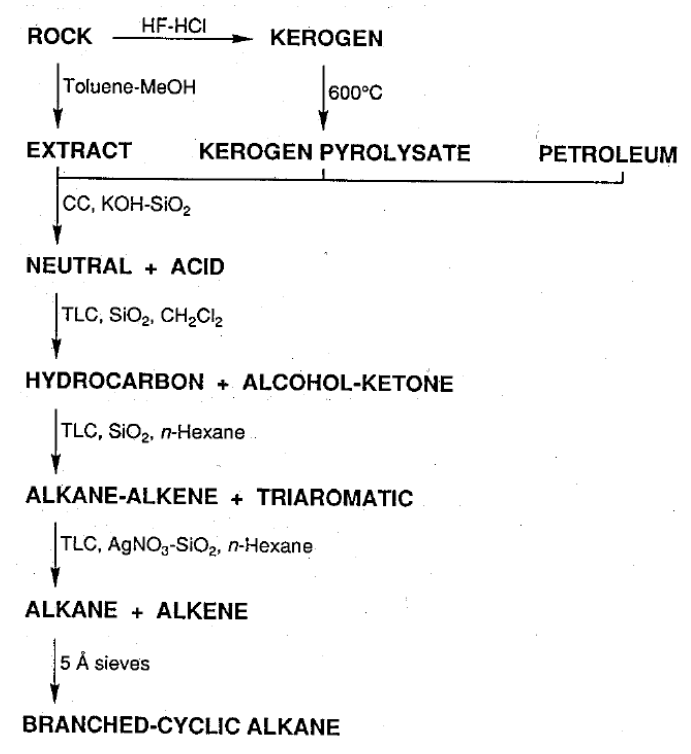

Scheme. Fractionnation of sedimentary organic matter. CC: column chromatography. TLC: thin layer chromatography

\section{Gas chromatography, mass spectrometry and isotopic analysis.}

Gas chromatographic analyses were performed using a Carlo Erba 4160 fitted with an on-column injector and a flame ionization detector (see figure captions for specific conditions). The fractions were eluted on fused-silica capillary columns with hydrogen. The gas chromatographic-mass spectrometric analysis were performed on a home-made gas chromatograph fitted with a Ross injector, coupled with a LKB $9000 \mathrm{~S}$ mass spectrometer (B type) or on a Varian 6000 gas chromatograph fitted with an on-column injector, coupled with a Nermag R10 quadrupole mass spectrometer. Conditions: helium carrier gas, electron impact (70 e.V.), source temperature $250^{\circ} \mathrm{C}$. Metastable experiments were performed on a Carlo Erba gas chromatograph coupled with a Kratos MS 80 mass spectrometer (EB type).

The ${ }^{13} \mathrm{C} /{ }^{12} \mathrm{C}$ composition and concentration of carbonates (Table 2$)$ were determined by analysis of the $\mathrm{CO}_{2}$ evolved by reaction of powdered samples with phosphoric acid $(\rho>1.89$ $\mathrm{g} / \mathrm{cm}^{3}$ ) at $50^{\circ} \mathrm{C}$ (Wachter and Hayes, 1985). After removal of water and non-condensible gases by cryogenic distillation, the carbon dioxide was quantified, then analysed by mass spectrometry (3-4 replicates). Yields of carbon dioxide are expressed in terms of calcium 
carbonate equivalents : (moles $\mathrm{CO}_{2} \times 100.086 \times 100$ )/sample dry weight. The ${ }^{13} \mathrm{C} /{ }^{12} \mathrm{C}$ compositions of $n$-alkanes from alkane fractions (3-4 replicates) were measured on a HewlettPackard gas chromatograph coupled with a combustion furnace $\left(\mathrm{CuO}, 850^{\circ} \mathrm{C}\right)$ coupled with a Finnigan Delta $S$ mass spectrometer (Freeman et al., 1990). Isotopic compositions, expressed in permil, are referred to the Pee Dee Belemnite standard: $\delta{ }^{13} \mathrm{C}=\left[\left({ }^{13} \mathrm{C} /{ }^{12} \mathrm{C}\right.\right.$ sample $\left.\left.{ }^{13} \mathrm{C} /{ }^{12} \mathrm{Cstd}\right) /\left({ }^{13} \mathrm{C} /{ }^{12} \mathrm{Cstd}\right)\right] \times 10^{3}$. The isotopic compositions of $19,25,28$ carbon-numbered $n$ alkanes and phytane are not reported due to nearly co-eluting unidentified substances (Lichtfouse et al., 1991).

\section{Identification of organic compounds}

Methylphenanthrenes, 2-methylanthracene, 9-methylanthracene and triaromatic steroids were identified by co-injection of pure standards (see also Radke et al., 1984, 1990, Ludwig et al., 1981, Lichtfouse, 1990, Lichtfouse et al., 1990). Other compounds were identified by their gas chromatographic and mass spectroscopic properties and by comparison with literature data: steranes (Seifert and Moldowan, 1979, Moldowan et al.,1980), diasteranes (Ensminger et al., 1978, Sieskind et al., 1991), diasterenes (Rubinstein and Albrecht, 1975, Sieskind and Albrecht, 1985), spirosterenes (Peakman et al., 1984) and de-A-diasterenes (Peakman et al., 1986). The configuration of steroids at position 24 was not determined because $24 \mathrm{R}$ and $24 \mathrm{~S}$ isomers nearly co-elute in routine gas chromatography (Maxwell et al., 1980). The names "pristane" or "phytane" refer to mixtures of their stereoisomers. The names of steroids follow the IUPAC-IUB rules (1972), but, for convenience, abbreviations are sometimes used in figures.

\section{RESULTS AND DISCUSSION}

\section{Carbonate content and ${ }^{13} \mathrm{C} /{ }^{12} \mathrm{C}$ composition}

The carbonate content of the samples ranges from 9 to $65 \%$ (Fig. 1). The rocks located in the basin center below $1500 \mathrm{~m}$ depth can be clearly divided into two facies which correspond with their geological age: carbonate-poor rocks from the Toarcian formation (shales, 9-15\% $\mathrm{CaCO}_{3}$ ), and carbonate-rich rocks from the Hettangian formation (marls, 35-65\% $\mathrm{CaCO}_{3}$ ). In this zone, carbonate in the marls is enriched by about $1.5 \%$ in ${ }^{13} \mathrm{C}$ relative to the shales. The ${ }^{13} \mathrm{C}$ content of the carbonates is inversely correlated with the abundance of carbonate (Fig. 2), presumably indicating dilution of diagenetically derived carbonate by increasing quantities of primary marine carbonate.
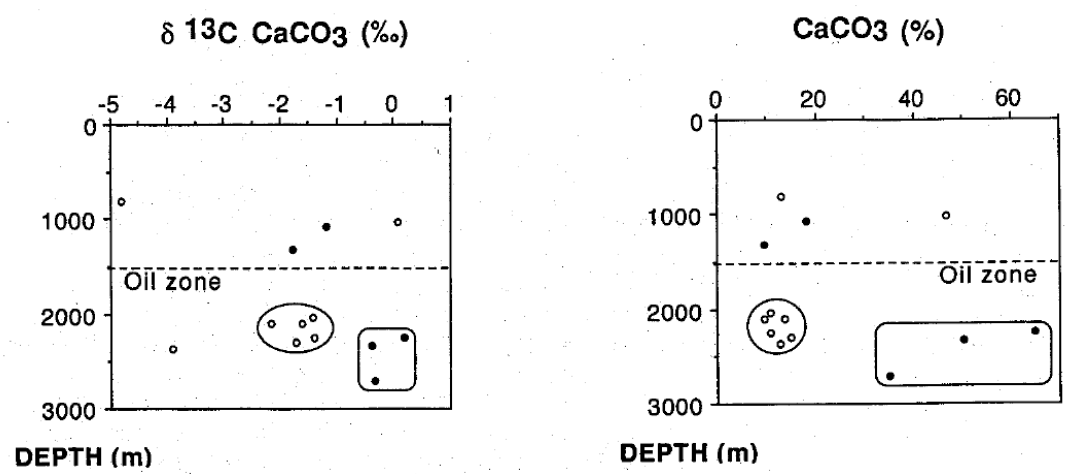

Figure 1. Carbonate isotopic compositions and carbonate contents of the sedimentary rocks from the Paris Basin versus depth. Note the higher carbonate content and isotopic enrichment of Hettangian rocks in the zone of petroleum generation (below $1500 \mathrm{~m}$ depth). Carbonate content is expressed in terms of calcium carbonate equivalents : (moles $\mathrm{CO}_{2} \times 100.086$ × 100)/sample dry weight. 


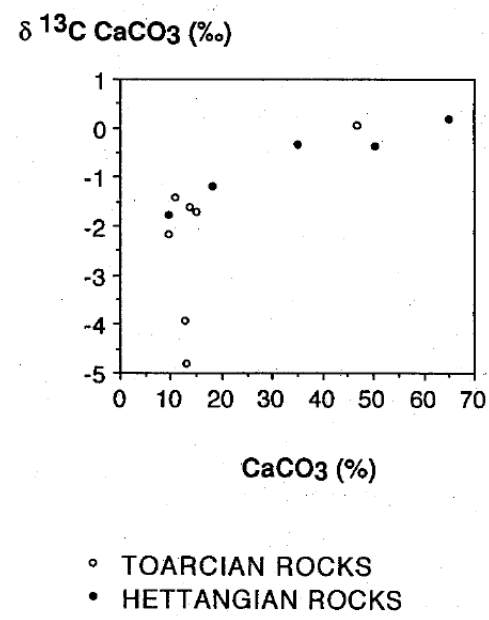

Figure 2. Isotopic compositions of carbonate versus carbonate content in the sedimentary rocks from the Paris Basin. Isotopic compositions increase with increasing carbonate contents in sediments containing more than $15 \%$ carbonate. Carbonate content is expressed in terms of calcium carbonate equivalents : (moles $\mathrm{CO}_{2} \times 100.086 \times 100$ )/sample dry weight.

\section{Alkane distributions}

In immature sedimentary rocks, located in the Eastern part of the basin, distributions of $n$-alkanes from extracts display modes at $\mathrm{C}_{17}$ and $\mathrm{C}_{29}$, with an odd-carbon predominance. These modes likely reflect both marine and terrigenous plant sources for the $n$-alkanes (Winters et al., 1969, Gelpi et al., 1968, 1970, Huc, 1976, Rieley et al., 1991). Contributions from bacteria are confirmed by identification of $\mathrm{C}_{31}-\mathrm{C}_{35}$ hopanes, mainly $17 \alpha, 21 \beta$ isomers, in all the samples studied (see also Ensminger et al., 1977, Ourisson et al., 1979, 1987). Pristane, phytane and polycyclic alkanes are major components in some samples.

In mature sedimentary organic matter and petroleums, distributions of $n$-alkanes from extracts favor low molecular-weight members, maximizing at $\mathrm{C}_{12}-\mathrm{C}_{16}$, without any notable odd-even predominance. The pristane/phytane ratio is always greater than 1 , suggesting less reducing paleoconditions (Tissot and Welte, 1984). The alkane distributions are very similar for all mature sediments and petroleums located in the center of the basin, making it difficult to postulate a genetic relationship (Tissot, 1987, I.F.P., unpublished results). 


\section{Isotopic compositions of n-alkanes}

The carbon isotopic compositions of $n$-alkanes from most rocks and petroleums examined in this investigation fall in a narrow range, about $2 \%$ (Fig. 3). This is in agreement with the relative homogeneity of the organic matter in the Paris Basin and also confirms that the Lias formations are probably the major source-rocks of the petroleums (Espitalié et al., 1987).

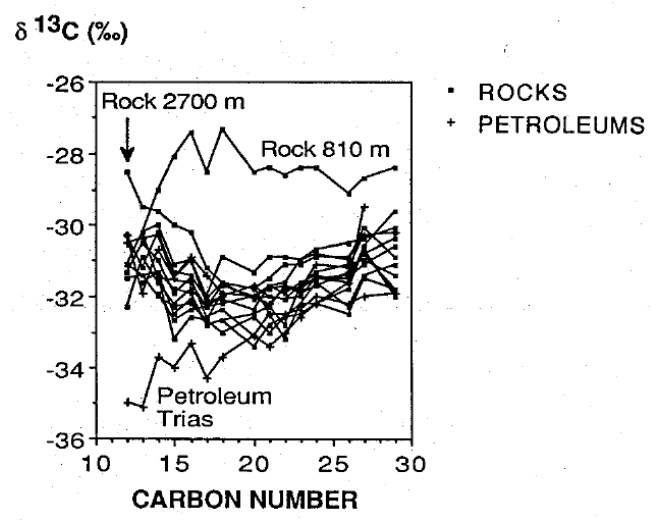

Figure 3. Carbon isotopic compositions of $n$-alkanes in petroleums and rock organic extracts from the Paris Basin. The isotopic compositions of $n$-alkanes from most rocks and petroleums fall in a narrow range (2\%). By comparison, short-chain $n$-alkanes from the most mature rock (Hettangian, $2700 \mathrm{~m}$ ) and the Trias petroleum are enriched and depleted in ${ }^{13} \mathrm{C}$ respectively. $n$-Alkanes from the shallowest sediment (Toarcian, $810 \mathrm{~m}$ ) are enriched in ${ }^{13} \mathrm{C}$.

Shorter-chain $\left(\mathrm{C}_{13}-\mathrm{C}_{18}\right)$ alkanes in the Hettangian rock from $2700 \mathrm{~m}$ depth are enriched in ${ }^{13} \mathrm{C}$ relative to most other $n$-alkanes from mature rocks, with the enrichment being most pronounced at the shortest chain lengths. This sedimentary rock is derived from the middle and deepest part of a basin noted for homogeneity of organic matter input (Espitalié et al., 1987, 1988, Tissot et al., 1971). Admixture of materials from some distinct source is thus an unlikely cause for the enrichment and effects of thermal maturation must be considered. It is possible either that the noted enrichment in ${ }^{13} \mathrm{C}$ indicates breakdown of some isotopically distinct source, present in all samples but yielding alkanes only at the greatest depth, or the prior generation and expulsion of isotopically depleted products of thermolytic cleavage. Normal kinetic isotope effects are presumably associated with such cleavage reactions and it is expected that their products will be depleted in ${ }^{13} \mathrm{C}$ (Welte, 1969, Sackett, 1978, Waples and Tornheim, 1978). According to the latter view, the shorter-chain $n$-alkanes extracted from the $2700 \mathrm{~m}$ depth sample represent a residue, with the isotopically depleted cleavage products having been lost by migration. Indeed, the highest migration ratio (88\%) was recorded at 2700 $\mathrm{m}$ depth, indicating that large amounts of hydrocarbons have been expelled (Espitalié et al., 1988).

In the same line of thought, the depletion in ${ }^{13} \mathrm{C}$ of short-chain $n$-alkanes from the Trias petroleum might be due to the preferential expulsion of ${ }^{13} \mathrm{C}$-depleted $n$-alkanes from the source-rock. However, the Trias petroleum could have a quite distinct unknown source, differing significantly either in maturity or initial inputs, thus giving a different isotopic curve.

In the shallowest sedimentary rock from the Toarcian at $810 \mathrm{~m}$ depth, the isotopic composition of most $n$-alkanes (ca. $-28.5 \%$ ) are enriched in ${ }^{13} \mathrm{C}$ to about $3 \%$ ocompared to other sedimentary rocks (ca. $-31.5 \% \circ$ ). Accordingly, it is possible that the extractable alkanes initially present in all sediments had isotopic compositions near those of the $810 \mathrm{~m}$ depth sample and that alkanes released later by catagenetic breakdown of kerogen are lighter. 
Steranes

In mature sediments, $\mathrm{C}_{26}-\mathrm{C}_{30}$ steranes are usually present as a complex mixture of isomers and are poorly resolved by single ion monitoring ( $\mathrm{SIM}, \mathrm{m} / \mathrm{z}=217)$ gas chromatography-mass spectrometry. Therefore, cholestane and diacholestane isomers $\left(\mathrm{C}_{27}\right)$ were selectively analysed by gas chromatography-mass spectrometry with metastable reaction monitoring (Fig. 4 and 5; Steen, 1986). In the sediment extracts from the Paris Basin, the major steranes and diasteranes are $\mathrm{C}_{27}-\mathrm{C}_{29}$ members. The minor presence of $\mathrm{C}_{21}-\mathrm{C}_{22}, \mathrm{C}_{26}$ and $\mathrm{C}_{30}$ steranes in each sample probably reflects the contribution of marine organisms to the organic matter (Mackenzie et al., 1982, Moldowan, 1984, Moldowan et al., 1990, 1991).

\section{CHOLESTANE STEREOISOMERS}

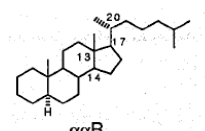

ari

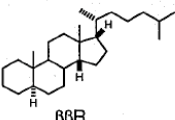

$\beta \beta R$

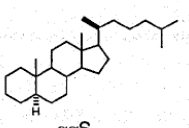

$\alpha \alpha S$<smiles>CC(C)CCCCCC1CCCCC12CCCCC21CCCCC1</smiles>

BBS

DIACHOLESTANE STEREOISOMERS
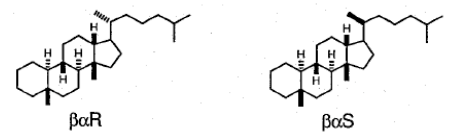

Figure 4. Molecular structures of $\mathrm{C}_{27}$ steranes occurring in petroleums and rock organic extracts from the Paris Basin. $\alpha$ and $\beta$ refer to the stereochemistry of the hydrogen atom of cholestane stereoisomers at position 14 and 17 , respectively ( $\alpha \alpha \mathrm{R}, \alpha \alpha S, \beta \beta \mathrm{R}, \beta \beta S)$. $\alpha$ and $\beta$ refer to the stereochemistry of the hydrogen atom of diacholestane stereoisomers at position 13 and 17 , respectively $(\beta \alpha R, \beta \alpha S)$. R and $S$ refer to the configuration at position 20 .
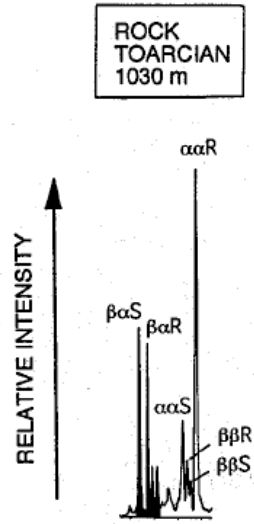

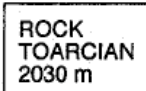

$2030 \mathrm{~m}$

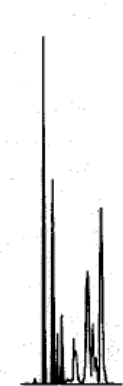

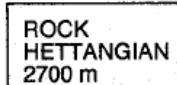

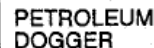

$1858 \mathrm{~m}$

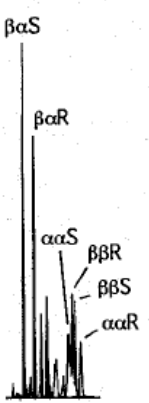

TIME

Figure 5. Metastable reaction fragmentograms for $\mathrm{C}_{27}$ steranes in petroleums and rock organic extracts from the Paris Basin, for the $372 \rightarrow 217$ transition. Diacholestane isomers (shaded) elute earlier than

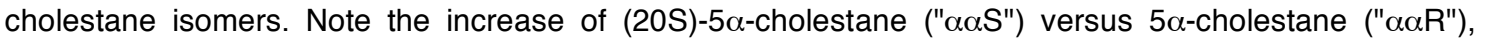
(20S)-13 $\beta, 17 \alpha$-diacholestane (" $\beta \alpha S^{\prime \prime) ~ v e r s u s ~(20 S)-5 ~} \alpha$-cholestane (" $\left.\alpha \alpha S^{\prime}\right),(20 R)-5 \alpha, 14 \beta, 17 \beta$-cholestane (" $\beta \beta R$ ") versus (20R)-5 $\alpha$-cholestane (" $\alpha \alpha R$ ") with increasing depth. Note also the similar fingerprints of the Hettangian sediment and the Dogger petroleum. Conditions: gas chromatography-mass spectrometry; fused-silica capillary column $(30 \mathrm{~m} \times 0.25 \mathrm{~mm})$, DB 17 phase $(0.1 \mu \mathrm{m})$, on column injector, Helium carrier gas (1.4 b.), temperature: $150-300^{\circ} \mathrm{C}$ at $3^{\circ} / \mathrm{min}$. E.I. (70 e.V., Kratos), $4 \mathrm{kV}$ acceleration voltage after the source. 
Three changes in the composition of the sterane mixture were observed with increasing depth, allowing the maturity of the organic matter to be followed closely (Fig. 5,6). The molecular parameters measure the relative concentration increase of 20S- versus 20R-steranes ("SR"), diasteranes versus non-rearranged steranes ("DIA") and $\beta \beta$ - versus $\alpha \alpha$-steranes ("BA"):

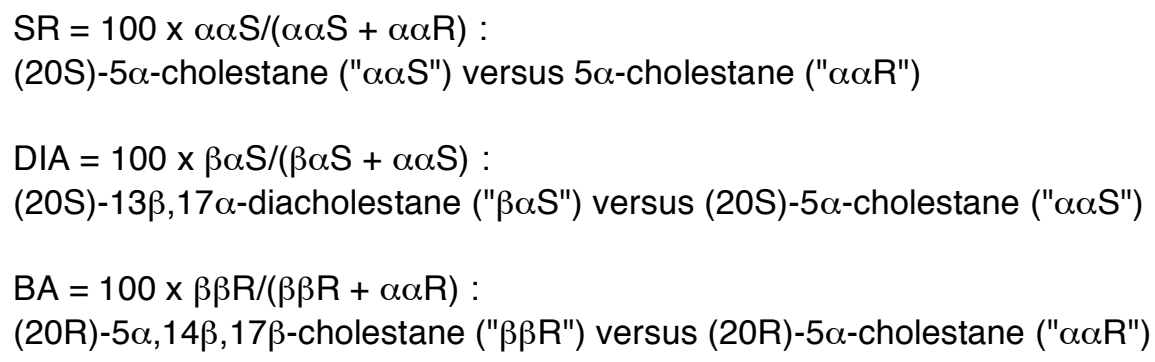

Molecular structures are shown in figure 4.

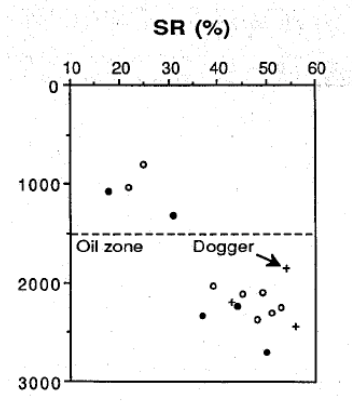

DEPTH (m)

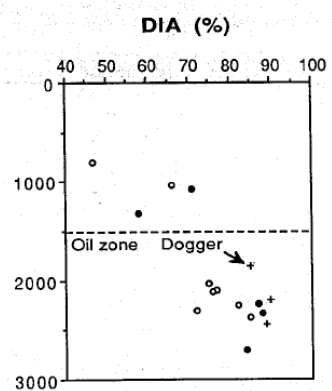

$\operatorname{DEPTH}(\mathbf{m})$

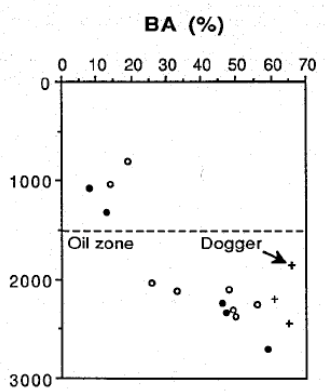

DEPTH (m)

$$
\begin{aligned}
& \text { - TOARCIAN ROCKS } \\
& \text { - HETTANGIAN ROCKS } \\
& + \text { PETROLEUMS }
\end{aligned}
$$

Figure 6. Steranes parameters versus depth in petroleums and rock organic extracts from the Paris Basin. Note the rapid increase of BA values $(2000-2500 \mathrm{~m})$ in the oil zone. A linear regression for Toarcian and Hettangian rocks below $1500 \mathrm{~m}$ gives Depth $=1607+14.4 \times \mathrm{BA}(r=0.76)$. The point on this line having the same $B A$ value as the Dogger petroleum $(B A=66 \%$, Depth $=1858 \mathrm{~m})$ has a depth of $2559 \mathrm{~m}$, suggesting a minimum distance of vertical migration of about $700 \mathrm{~m}$. Similar regressions using $\mathrm{SR}$ and DIA give distances of about $470 \mathrm{~m}$ and $480 \mathrm{~m}$, respectively.

The rapid increase of BA between 2000 and $2500 \mathrm{~m}$, previously observed in the Toarcian shales for steranes and porphyrins (Mackenzie et al. 1980a,b), reflects the rapid transformation of the organic matter within a relatively short depth interval (ca. 2000-2500 m). It is of interest to note that these trends also coincide with changes in organic matter fluorescence observed by Alpern and Cheymol (1978) in the Toarcian shales.

Depth is used as a proxy for maturation because sedimentary rocks from the center of the basin (below $1500 \mathrm{~m}$ depth) have experienced a rather regular subsidence as shown by burial-history curves (Tissot et al., 1971). Sedimentary rocks located in eastern area, above $1500 \mathrm{~m}$ depth, have been slightly uplifted. In the catagenetic zone, the SR and BA parameters indicate that Hettangian sedimentary rocks are in the same maturity range as the Toarcian shales although DIA values suggest the Hettangian rock is slightly more mature. Petroleums are often in the most mature range, close to the most mature Toarcian or Hettangian rocks which appear therefore to be the dominant sources. A comparison of the $372 \rightarrow 217$ fragmentograms also shows that the Dogger petroleum is most likely derived from deep Hettangian sediments (Fig. 5). 


\section{Sterenes}

The extracts which contain substantial amounts of alkenes, mainly steroid derivatives, are restricted to the diagenetic zone, above $1500 \mathrm{~m}$ depth. Monitoring ion currents at $\mathrm{m} / \mathrm{z}=257$, the major diasterenes are $\mathrm{C}_{27}-\mathrm{C}_{29}$ members with lower amounts of $\mathrm{C}_{21}-\mathrm{C}_{24}$ and $\mathrm{C}_{30}$ members, and 20S-20R isomeric doublets occur in the $\mathrm{C}_{23}-\mathrm{C}_{30}$ range. Diasterenes and diasteranes, absent in living organisms, are probably derived from sterols via sterenes under acidic conditions possibly by mineral catalysis (Rubinstein et al., 1975; Dastillung and Albrecht, 1977; Sieskind and Albrecht, 1985). The presence of $\mathrm{C}_{27}-\mathrm{C}_{29}$ spirosterenes and spirodiasterenes (20R and 20S), detected by monitoring ion currents at $\mathrm{m} / \mathrm{z}=206,220$ and 234, provides additional evidence for molecular rearrangements under acidic conditions (Peakman et al., 1984, 1988; Peakman and Maxwell, 1988). Traces of $\mathrm{C}_{23}-\mathrm{C}_{25}$ de-Adiasterenes, as doublets, were also detected by monitoring the ion current at $\mathrm{m} / \mathrm{z}=203$ (Peakman et al., 1986).

\section{Methylphenanthrenes, methylanthracenes}

The parameters based on alkyl phenanthrenes have previously been found to be very useful indicators of maturity for sedimentary rocks containing type-III organic matter, such as coals (Radke and Welte, 1983; Garrigues et al., 1988). In the extracts and petroleums from the Paris Basin, which contain type-II organic matter, the methyphenanthrene indexes MPI 1 and MPI 3 do not show significant variations with increasing depth (Fig. 7, Lichtfouse, 1990, Lichtfouse et al., 1989). However, methylphenanthrenes also occur in triaromatic fractions from kerogen pyrolysates, with notable amounts of methylanthracenes (Fig. 8, 9). The absence of alkyl anthracenes in the extracts and petroleums from the Paris Basin suggests that these substances are formed during pyrolysis of the kerogen from unknown precursors. The concentration of methylphenanthrenes (i.e. 2-MP) relative to methylanthracenes (i.e. 2-MA) increases with depth (Fig. 9, 10), allowing definition of a novel maturity parameter, the "MethylPhenanthrene-Anthracene" parameter:

$M P A=2-M P / 2-M A$
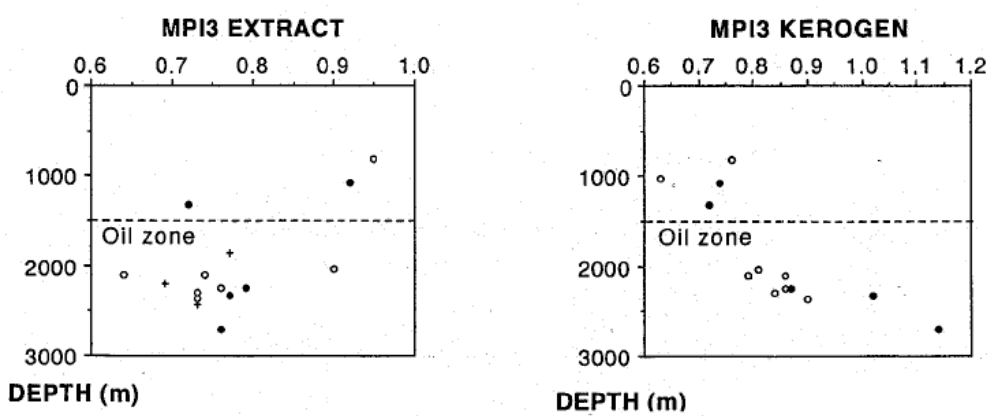

DEPTH (m)

\footnotetext{
- toARCIAN ROCKS

- hetTANGIAN ROCKS

+ PETROLEUMS
}

Figure 7. Methyphenanthrenes parameter versus depth in the petroleums, organic extracts and kerogen pyrolysates from the Paris Basin. Note the increase of MPI3 for kerogen pyrolysates below $2000 \mathrm{~m}$. MPI3 $=(2-\mathrm{MP}+3-\mathrm{MP}) /(1-\mathrm{MP}+4-\mathrm{MP}+9-\mathrm{MP})$, calculated with relative intensities on the $\mathrm{m} / \mathrm{z}=192$ ion current.

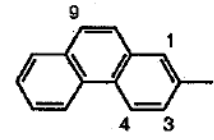

2-Methylphenanthrene (2-MP)

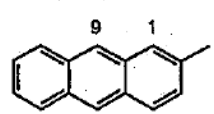

2-Methylanthracene

(2-MA)

Figure 8. Molecular structures of 2-methylphenanthrene and 2-methylanthracene. 
In kerogen pyrolysates, the MPI 3 and MPA give low values for immature samples, above $1500 \mathrm{~m}$ (Fig. 7, 10). A dramatic increase is observed below $2000 \mathrm{~m}$ suggesting the notable transformation of the organic matter at this stage. The mature rocks can be clearly separated into two classes with MPA and MPI 3; the pyrolysates from Hettangian rocks give significantly higher values than Toarcian rocks, suggesting the higher thermal maturity of the Hettangian rocks. Alternatively, the higher carbonate content of Hettangian rocks in the center of the basin suggests that a facies effect is also possible. Indeed, Toarcian and Hettangian rocks of about the same depth, for example at $2243 \mathrm{~m}$ and $2253 \mathrm{~m}$, should have experienced approximately the same thermal history. Therefore the apparent higher maturities of the Hettangian rocks can not be explained solely by a greater amount of thermal stress.

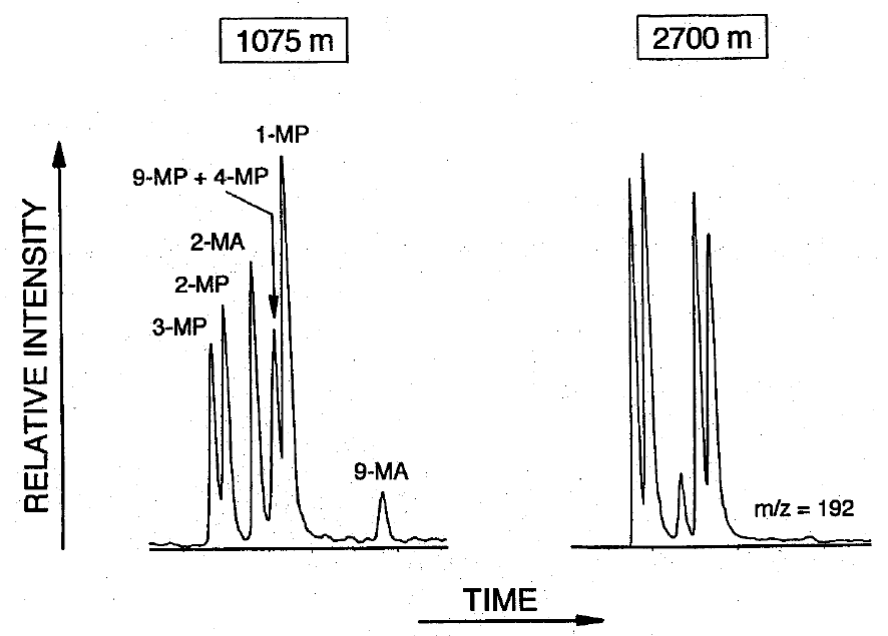

Figure 9. Mass fragmentograms showing the methylphenanthrenes (MP) and methylanthracenes (MA) in kerogen pyrolysates from the Paris Basin sedimentary rocks. Note the increase of 3-methyl- and 2methylphenanthrenes versus 9-methyl, 4-methyl and 1-methyl homologues, with increasing depth. Note also the increase of methylphenanthrenes versus methylanthracenes, with increasing depth. 1Methylanthracene possibly coelutes with 9-methyl- or 1-methylphenanthrene (Dr. M. Radke, personnal communication). Conditions: gas chromatography-mass spectrometry: fused-silica capillary column (60 m x $0.32 \mathrm{~mm})$, DB 1 phase $(0.25 \mu \mathrm{m})$, on column injector, Helium carrier gas $(1.4 \mathrm{~b}$.$) ; temperature: 60^{\circ} \mathrm{C}(4$ $\min$.), $60-110^{\circ} \mathrm{C}$ at $10^{\circ} / \mathrm{min} ., 110-325^{\circ} \mathrm{C}$ at $3^{\circ} / \mathrm{min}$. , E.I. (70 e.V., Nermag).

These kerogen parameters might be particulary useful to measure the thermal evolution of marine organic matter (type-II), where classical parameters are usually inadequate : in the Paris Basin, for example, the measurement of maturity by means of vitrinite reflectance is unfeasible because organic particles determined as vitrinite are generally not vitrinite (Alpern and Cheymol, 1978; Durand et al., 1986). Moreover, parameters based on the kerogen composition represent the evolution of the bulk organic matter because the mass of kerogen constitutes more than $80 \%$ of the total organic matter (Tissot and Welte, 1984). We note that values as high as 4.7 for MPI 3 and 50 for MPA were recorded for a Paleozoic sediment of type-III organic matter, located at $3150 \mathrm{~m}$ in the eastern part of the basin. 


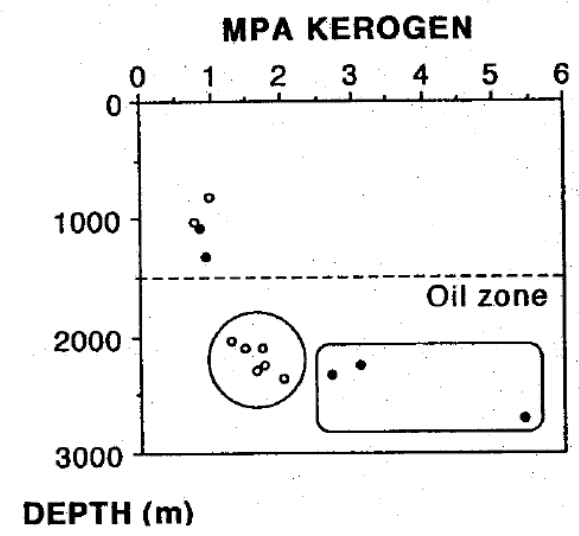

- TOARCIAN ROCKS

- HETTANGIAN ROCKS

Figure 10. MethylPhenanthrene-Anthracene parameter versus depth in kerogen pyrolysate of Paris Basin sedimentary rocks. Hettangian rocks give higher MPA values than Toarcian rocks in the oil zone. MPA=2MP/2-MA, calculated with relative intensities on the $\mathrm{m} / \mathrm{z}=192$ ion current.

\section{Aromatic steroids}

In a previous study of Toarcian shales from the Paris Basin, changes in the composition of mono- and triaromatic steroid mixtures were related to the transformation of the organic matter with increasing depth (Mackenzie et al., 1981). For example, the relative concentration of short-chain versus long-chain triaromatic steroids increases with depth, presumably as a result of maturation (Fig. 11, 12). The Dogger and the Domerian petroleums show similar fragmentograms, whereas the Trias petroleum has a much higher relative concentration of short-chain triaromatic steroids (Fig. 13). This clear difference probably reflects the higher maturity or a different input for the Trias petroleum, as proposed earlier in the isotopic section.

\section{TRIAROMATIC STEROIDS}

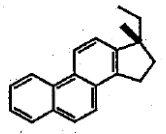

$\mathrm{C}_{20}$

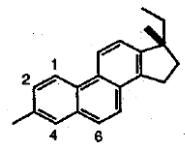

$3-\mathrm{C}_{21}$

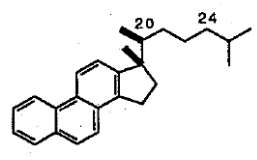

$\mathrm{C}_{26} \mathrm{~S}$

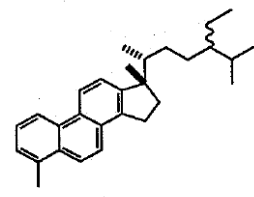

$4-C_{29} R$

Figure 11. Molecular structures of triaromatic steroids, including methyltriaromatic steroids. $\mathrm{R}$ and $\mathrm{S}$ refer to the stereochemistry at position 20. 3- and 4- indicate the position of the methyl group on the aromatic nucleus. 


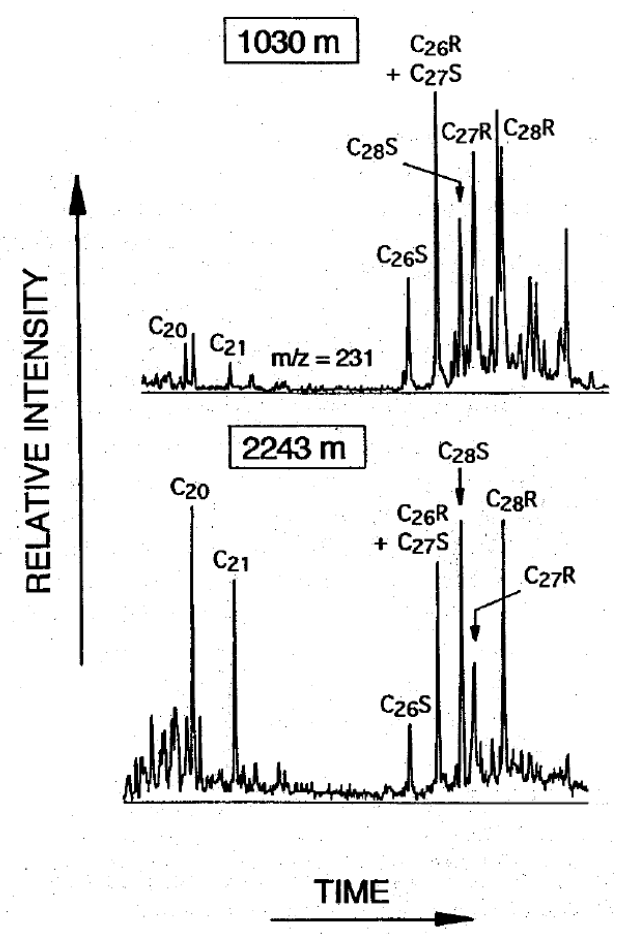

Figure 12. Mass fragmentograms showing the triaromatic steroids in organic extracts of Paris Basin sedimentary rocks. Note the increase of short chain versus long chain triaromatic steroids with increasing depth (see also Mackenzie et al., 1981). Two unidentified compounds coelute with $C_{27} R$, as seen by GCMS on a more polar phase (DB 17). Conditions: gas chromatography-mass spectrometry: fused-silica capillary column $(25 \mathrm{~m} \times 0.3 \mathrm{~mm})$, SE 30 phase $(0.1 \mu \mathrm{m})$, Ross injector, Helium carrier gas $(1 \mathrm{~b}$.); temperature: $150-300^{\circ} \mathrm{C}$ at $2^{\circ} / \mathrm{min}$. , E.I. (70 e.V., LKB 9000S).

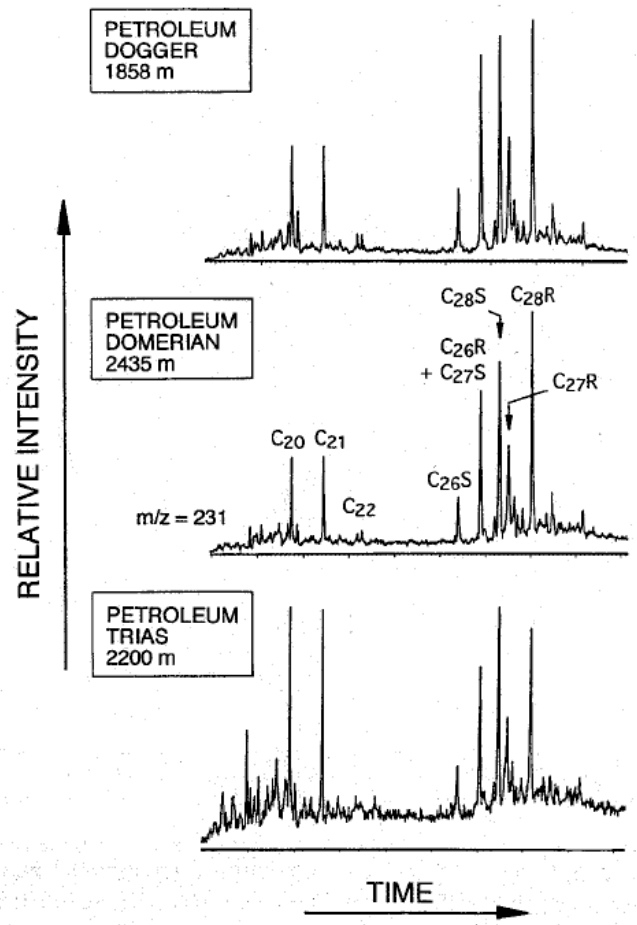

Figure 13. Mass fragmentograms showing the triaromatic steroids in petroleums from the Paris Basin. Note the highest concentration of short chain versus long chain triaromatic steroids in the Trias petroleum, also seen for methyltriaromatic steroids on $\mathrm{m} / \mathrm{z}=245$ fragmentograms. Conditions: see Fig. 12. 
Triaromatic steroids methylated at position 2, 3 or 6 , first detected as substances of possible geochemical interest by Riolo et al. (1986), were identified later in the Paris basin sedimentary rocks by comparison with synthetic substances and proposed as maturity parameters (Fig. 14, Lichtfouse et al., 1989, 1990). Though their mode of formation remains unknown, we also predicted a common precursor for 3-methyltriaromatic steroids, 3methylsteranes and 3-carboxysteranes based on their structural comparison (Lichtfouse, 1990, Lichtfouse et al., 1993). This hypothesis is supported by the identification of $3 \beta$-alkylsteranes in various sediments (Summons and Capon, 1988, 1991, Dahl et al., 1992).

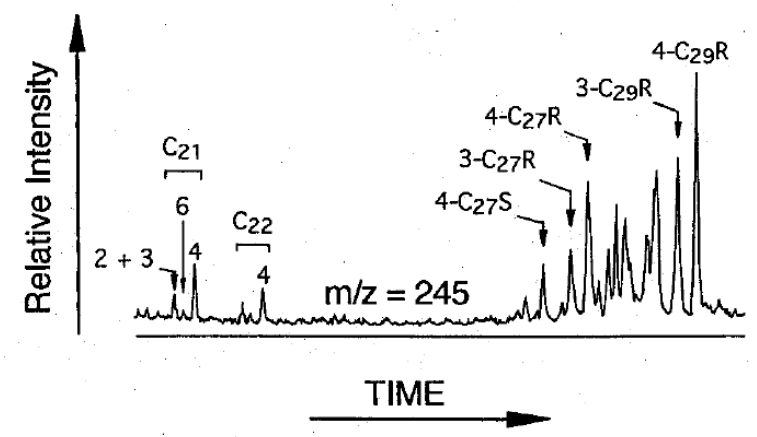

Figure 14. Mass fragmentograms showing the methyltriaromatic steroids in an organic extract of a Paris Basin sedimentary rock (depth $2243 \mathrm{~m}$ ). Numbers refer to the position of the methyl group on the steroid. Unidentified compounds coelute with $3-C_{27} R$ and $3-C_{29} R$, as seen by GC-MS on a more polar phase (DB 17). $2-C_{21}$ elutes before $3-C_{21}$ on a DB 17 phase. Conditions: see Fig.12.

The relative concentration of triaromatic steroids methylated at postion 2, 3 or 6 versus 4-methyl homologs increases with depth (Fig. 15). This trend is similar to that observed in typeIII organic matter for methylphenanthrenes (Radke and Welte, 1983), which are structurally similar to triaromatic steroids. Accordingly, methylphenanthrenes could eventually derive from methyltriaromatic steroids after degradation of the $D$ ring. The evolution of the organic matter in the Paris basin was also followed using the SL parameter, an index based on the relative abundance of short-chain-length triaromatic steroids (Mackenzie et al., 1981), and a novel parameter based on MethylTriaromatic Steroids (Fig. 16). Expressions for these parameters are:

$\mathrm{SL}=100 \times \mathrm{C}_{20} /\left(\mathrm{C}_{20}+\mathrm{C}_{26} \mathrm{~S}\right)$

MTS $=100 \times\left(2-C_{21}+3-C_{21}\right) /\left(2-C_{21}+3-C_{21}+4-C_{21}\right)$

Molecular structures are shown in Figure 11. 


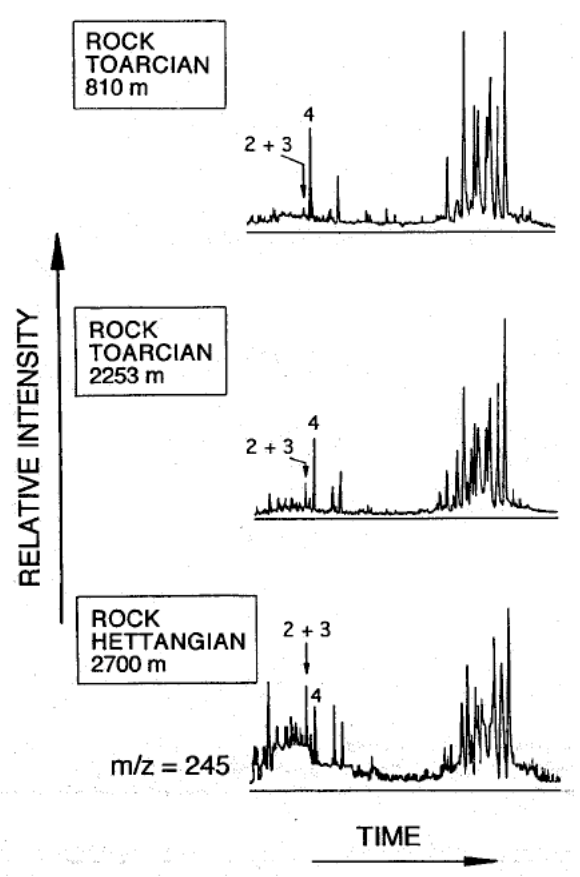

Figure 15. Mass fragmentograms showing the methyltriaromatic steroids from organic extracts of Paris Basin sedimentary rocks. Note the increase of 2-methyl- and 3-methyltriaromatic steroids $\left(2+3, \mathrm{C}_{21}\right)$ versus the 4 methyl homolog (4) with increasing depth. Conditions: see Fig. 12.

As seen earlier for kerogen parameters, Hettangian rocks give significantly higher values for SL and MTS than Toarcian rocks in the catagenetic zone (Fig. 16). This distinction could result from a difference in thermal maturity or reflect a facies effect between the Hettangian marls and the Toarcian shales. Furthermore, the only presence of 3-methyl homologues $\left(\mathrm{C}_{29}\right)$ among methyltriaromatic steroids in the immature evaporite sedimentary rocks from the Mulhouse Basin, France, suggests a strong facies dependance of the MTS parameter (Fache-Dany, 1990). In a series of sedimentary rocks of increasing depth from the Kimmeridge formation, the MTS values also suggest an influence from both maturity and facies (R. Houghton, pers. commun.). In the Monterey formation, the MTS values show a drastic increase in the zone of petroleum generation (E. Idiz, pers. commun.).
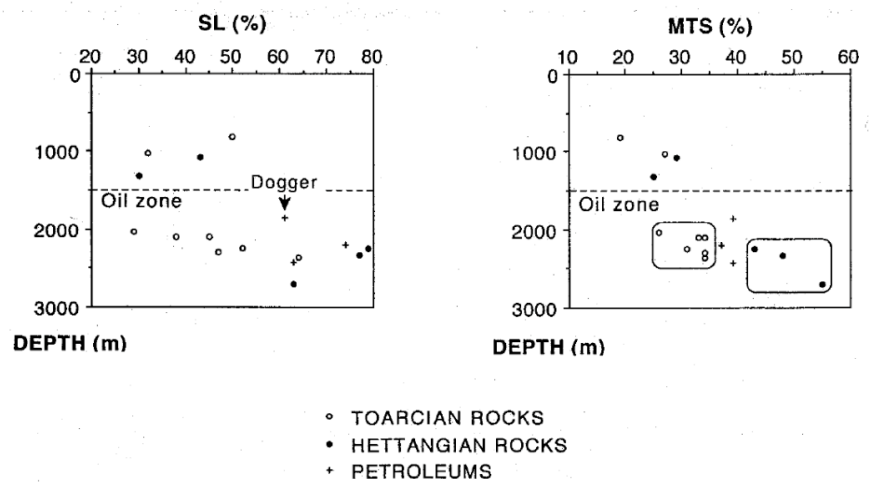

Figure 16. Aromatic steroid parameters versus depth in organic extracts of Paris Basin sedimentary rocks and petroleums. Hettangian rocks give higher SL and MTS values than Toarcian rocks in the oil zone. Note the rapid increase of SL and MTS below $2000 \mathrm{~m}$. Note also the anomalous high maturity of the Dogger petroleum for its depth, relative to the general trend: linear regressions for Toarcian and Hettangian rocks below 1500 m give Depth $=1911+6.6 \times \mathrm{SL}(r=0.57)$ and Depth $=1624+17.2 \times$ MTS $(r=0.80)$. The calculated depths for the SL $(61 \%)$ and MTS $(39 \%)$ values of the Dogger petroleum are $2311 \mathrm{~m}$ and $2296 \mathrm{~m}$, respectively, suggesting a minimum distance of upward migration of about 450 and $440 \mathrm{~m}$. 
Like most of the molecular parameters, SL and MTS show an increase below $2000 \mathrm{~m}$ for petroleums and Hettangian rocks, suggesting a rapid transformation of the organic matter in a relatively short depth interval. The SL and MTS values of the petroleums are intermediate between those of Toarcian and Hettangian sedimentary rocks. An exclusive generation from Toarcian rocks is therefore unlikely because petroleums are usually subjected to lower thermal stress than their source-rocks, after expulsion. On the other hand, the Transformation Ratio of the organic matter in Hettangian rocks $(T R=80 \%)$ is higher than in Toarcian rocks (TR $=40 \%$ ), based on Rock-Eval pyrolysis in the center of the basin (Espitalie et al., 1987). An important contribution of organic matter from the Hettangian sediments is also likely because Hettangian source-rocks are generally more mature than Toarcian source-rocks, according to Rock-Eval Pyrolysis parameters (i.e. Tmax parameter, Espitalié et al., 1987). Moreover, carbonate-rich sediments have also been widely recognized as excellent source beds for petroleum generation (Jones, 1984, Palacas, 1988) and a zone of oil production has been found recently within the Hettangian formation below Paris.

\section{Migration of the organic matter}

The minimal distance of vertical upward migration of a petroleum can be estimated by the following difference:

- (depth of the source-rock having the same maturity as the petroleum, calculated by regression of the maturity-depth plots of mature source-rocks) minus (depth of the petroleum reservoir).

This concept is based on the following observation: the Dogger petroleum displays an anomalous high maturity for its depth $(1858 \mathrm{~m})$ relative to the general trend of the mature source-rocks, suggesting that the organic matter has migrated from source rocks located deeper (see calculations in Fig. 6, 16). By linear regression of the maturity-depth points of Toarcian and Hettangian rocks in the zone of petroleum generation, it is possible to estimate the theorical depth of the source-rock and, therefore, the minimal distance of vertical migration. Using sterane and triaromatic steroid parameters, the calculated source-rock depth ranges from 2300 to $2560 \mathrm{~m}$, thus giving a minimal distance of vertical migration from $440 \mathrm{~m}$ to $700 \mathrm{~m}$. In the zone of petroleum generation, the maturity-depth points of Domerian and Trias petroleums are close to the general trend of mature source-rocks (Fig. 6, 16). According to the previous concept, these petroleums should have experienced a low vertical distance of upward migration.

The true migration distance should be corrected by the following points: 1) the calculation should take into account the horizontal migration. 2) Usually, the maturity of a source-rock will increase faster than the maturity of the petroleum generated by this source-rock due to higher thermal stress and higher mineral catalysis inside the source-rock. Few exceptions are possible, like petroleums occurring in pools located deeper than their sourcerocks and, therefore, probably subjected to higher thermal stress. 3) Various maturity parameters should be used to avoid possible source or facies effects. 4) Other regressions than linear might better follow the maturity-depth trend. 5) Anomalous high maturities might also be detected in basins which have locally high geothermal gradients.

\section{CONCLUSION}

In the zone of petroleum generation of the Paris Basin, Hettangian source-rocks are distinguished from Toarcian source rocks by higher carbonate content, ${ }^{13} \mathrm{C}$-enriched carbonates and higher values of molecular maturity parameters. The intermediate maturity of the petroleums show the possible migration of the organic matter from the Toarcian and Hettangian formations. Excluding the deepest Hettangian source-rock and the Trias petroleum, the isotopic compositions of $n$-alkanes from mature sediments and petroleums fall in a narrow range.

The MPI 3 parameter and the novel MPA parameter based on the relative concentration of 1-methylphenanthrene and 2-methylanthracene in the kerogen pyrolysates, show dramatic increases in the oil window, suggesting the possible use of these parameters to follow the evolution of type-II "marine" organic matter. Similar increases were also observed with 
parameters based on sterane abundances and a novel MTS parameter based on the relative concentration of methyltriaromatic steroids in the organic extracts. Such trends indicate a rapid transformation of the organic matter within a relative short depth interval (2000-2500 m).

The minimal vertical distance of migration of a petroleum can be estimated by the following difference: (depth of the source-rock having the same maturity as the petroleum, calculated by regression of the maturity-depth plots of mature source-rocks) minus (depth of the petroleum). Accordingly, the anomalous high values of molecular parameters observed for the Dogger petroleum, relative to its depth, suggest an upward migration from the source-rocks currently located at about $2300-2560 \mathrm{~m}$, which is in good agreement with the study of Espitalié et al. (1988).

\section{ACKNOWLEDGEMENTS}

This research was supported by the Institut Français du Pétrole, the Centre National de la Recherche Scientifique, Indiana University (DOE Grant DE-FG02-88ER13978) and the Institut National de la Recherche Agronomique. We thank B. Tissot, B. Durand, A. Huc, G. Bessereau, F. Marquis, C. Leblond, M. Da Sylva, C. St Paul (Institut Français du Pétrole), J.-M. Trendel, G. Teller, P. Wehrung, P. Blanc, D. Durrenberger (Université Louis Pasteur), J. Oudin (Total), K. Freeman, J. Collister, S. Studley, R. Droppo and D. Merritt (Indiana University) and E. Idiz (Shell) for helpful discussions or assistance. Helpful and critical comments have been provided by Dr. Jean Espitalié, Dr. Torren Peakman and two anonymous reviewers.

\section{REFERENCES}

Alpern B. and Cheymol D. (1978) Réflectance et fluorescence des organoclastes du Toarcien du bassin de Paris en fonction de la profondeur et de la température. Rev. Inst. Fr. Pétr. 33, 515-535.

Béhar F., Leblond C. and Saint-Paul C. (1989) Analyse quantitative des effluents de pyrolyse en milieu ouvert et fermé. Rev. Inst. Fr. Pétr. 44, 387-411.

Dahl J., Moldowan J. M., McCaffrey M. A. and Lipton P. A. (1992) A new class of natural products revealed by $3 \beta$-alkyl steranes in petroleum. Nature 355, 154-157.

Dastillung M. and Albrecht P. (1977) $\Delta^{2}$-sterenes as diagenetic intermediates in sediments. Nature 269, 678-679.

Durand B., Alpern B., Pittion J. L. and Pradier B. (1986) Reflectance of vitrinite as control of thermal history of sediments. In Thermal modelling in sedimentary basins (Ed. Burrus J.), pp. 441-474. Technip, Paris.

Ensminger A., Albrecht P., Ourisson G. and Tissot B. (1977) Evolution of polycyclic alkanes under the effect of burial (Early Toarcian shales, Paris basin). In Advances in Organic Geochemistry1975 (Ed. Campos R. and Goñi J.) pp. 45-52. ENADIMSA, Madrid.

Ensminger A., Joly G. and Albrecht P. (1978) Rearranged steranes in sediments and crude oils. Tetrahedron Lett. 18, 1575-1578.

Espitalié J., Marquis F., Sage L. and Barsony I. (1987) Géochimie organique du bassin de Paris. Rev. Inst. Fr. Pet. 42, 271-302.

Espitalié J., Maxwell J. R., Chenet Y. and Marquis F. (1988) Aspects of hydrocarbon migration in the Mesozoic in the Paris Basin as deduced from an organic geochemical survey. Org. Geochem. 13, 467-481.

Fache-Dany F. (1990) Etude des marqueurs moléculaires en série évaporitique: le bassin potassique du sud de l'Alsace. Ph.D. dissertation, Univ. Strasbourg. 
Freeman K. H., Hayes J. M., Trendel J.-M. and Albrecht P. (1990) Evidence from carbon isotope measurements for diverse origins of sedimentary hydrocarbons. Nature 343, 254-256.

Garrigues P., De Sury R., Angelin M. L., Bellocq J., Oudin J. L. and Ewald M. (1988) Relation of the methylated hydrocarbon distribution pattern to the maturity of organic matter in ancient sediments from the Mahakam delta. Geochim. Cosmochim. Acta 52, 375-384.

Gelpi E., Oró J., Schneider H. J. and Bennett E. O. (1968) Olefins of high molecular weight in two microscopic algae. Science 161, 700-702.

Gelpi E., Schneider H. J., Mann J. and Oró J. (1970) Hydrocarbons of geochemical significance in microscopic algae. Phytochem. 9, 603-612.

Huc A. Y. (1976) Mise en évidence de provinces géochimiques dans les schistes bitumineux du Toarcien de l'Est du bassin de Paris. Rev. Inst. Fr. Pet. 31, 933-953.

IUPAC-IUB (1972) Definitive rules for nomenclature of steroids. Pure Appl. Chem. 31, 285-322.

Jones R. W. (1984) Comparison of carbonate and shale source rocks. In Petroleum geochemistry and source rock potential of carbonate rocks (Ed. Palacas J. G.) pp. 163-180, The American Association of Petroleum Geologists, Tulsa, Oklahoma, U.S.A.

Koons C. B., Bond J. G. and Peirce F. L. (1974) Effects of depositional environment and postdepositional history on chemical composition of Lower Tuscaloosa oils. AAPG Bull. 58, $1272-1280$.

Leythaeuser D., Hollerbach A. and Hagemann H. W. (1977) Source rock/crude oil correlation based on distribution of $\mathrm{C}_{27+}$-cyclic hydrocarbons. In Advances in Organic Geochemistry 1975 (Ed. Campos R. and Goñi J.) pp. 3-20. ENADIMSA, Madrid.

Lichtfouse E. (1990) Nouveaux stéroides aromatiques fossiles. Ph.D. Dissertation, Univ. Strasbourg, France, 1989. Technip, Paris.

Lichtfouse E., Albrecht P. and Behar F. (1993) 3-Methyltriaromatic steroids in sediments. Molecular fossils with unknown precursors. in Polycyclic Aromatic Compounds (Ed. Garrigues Ph. and Lamotte M.) pp.635-638. Gordon and Breach Science Publishers, Amsterdam.

Lichtfouse E., Freeman K. H., Collister J. W. and Merritt D. A. (1991) Enhanced resolution of organic compounds from sediments by isotopic gas chromatography-combustion-mass spectrometry. J. Chromatogr. 585, 177-180.

Lichtfouse E., Riolo J. and Albrecht P. (1990) Occurrence of 2-methyl-, 3-methyl- and 6methyltriaromatic steroid hydrocarbons in geological samples. Tetrahedron Lett. 31, 3937-3940.

Lichtfouse E., Riolo J., Albrecht P. and Behar F. (1989) Short chain 3-methyltriaromatic steroids in main shales from the Paris basin, a novel maturity indicator. $14^{\text {th }}$ Meeting on Organic Geochemistry, Paris, France.

Ludwig B., Hussler G., Chappe B. and Albrecht P. (1981) $C_{26}-C_{29}$ Triaromatic steroid derivatives in sediments and petroleums. Tetrahedron lett. 22, 3313-3316.

Mackenzie A. S., Brassell S. C., Eglinton G. and Maxwell J. R. (1982) Chemical fossils: the geological fate of steroids. Science 217, 491-504.

Mackenzie A. S., Hoffmann C. F. and Maxwell J. R. (1981) Molecular parameters of maturation in the Toarcian shales, Paris Basin, France. III. Changes in aromatic steroid hydrocarbons. Geochim. Cosmochim. Acta 45, 1345-1355. 
Mackenzie A. S., Patience R. L., Maxwell J. R., Vandenbroucke M. and Durand B. (1980a) Molecular parameters of maturation in the Toarcian shales, Paris Basin, France. I. Changes in the configurations of acyclic isoprenoid alkanes, steranes and triterpanes. Geochim. Cosmochim. Acta 44, 1709-1721.

Mackenzie A. S., Quirke J. M. E. and Maxwell J. R. (1980b) Molecular parameters of maturation in the Toarcian shales, Paris Basin, France. II. Evolution of metalloporphyrins. In Advances in Organic Geochemistry 1979 (Ed. by Douglas A. G. and Maxwell J. R.), pp. 239-248. Pergamon, Oxford.

Maxwell J. R., Mackenzie A. S. and Volkman J. K. (1980) Configuration at C-24 in steranes and sterols. Nature 286, 694-697.

Mc Carthy R. D. and Duthie A. H. (1962) A rapid quantitative method for the separation of free fatty acids from other lipids. J. Lipid Res. 3, 117-119.

Moldowan J. M. (1984) $\mathrm{C}_{30}$-steranes, novel markers for marine petroleums and sedimentary rocks. Geochim. Cosmochim. Acta 48, 2767-2768.

Moldowan J. M., Fago F. J., Lee C. Y., Jacobson S. R., Watt D. S., Sloughi N.-E., Jeganathan A. and Young D. C. (1990) Sedimentary 24- $n$-Propylcholestanes, molecular fossils diagnostic of marine algae. Science 247, 309-312.

Moldowan J. M., Lee C. Y., Watt D. S., Jeganathan A., Sloughi N.-E. and Gallegos E. J. (1991) Analysis and occurrence of $\mathrm{C}_{26}$-steranes in petroleum and source rocks. Geochim. Cosmochim. acta 55, 1065-1081.

Moldowan J. M., Seifert W. K., Haley M. J. and Djerassi C. (1980) Proof of structure by synthesis of $5 \alpha, 14 \beta, 17 \beta(\mathrm{H})$-cholestane $(20 \mathrm{R})$, a major petroleum sterane. Correction with previous assignement. Geochim. Cosmochim. Acta 44, 1613.

O'Connor J. G., Burow F. H. and Norris M. S. (1962) Determination of normal parafins in $\mathrm{C}_{20}$ to $\mathrm{C}_{32}$ parafin waxes by molecular sieve adsorption. Anal. Chem. 34, 82-85.

Ourisson G., Albrecht P. and Rohmer M. (1979) The hopanoids, paleochemistry and biochemistry of a group of natural products. Pure Appl. Chem. 51, 709-729.

Ourisson G., Rohmer M. and Poralla K. (1987) Microbial lipids betrayed by their fossils. Microbiol. Sci. 4, 52-57.

Palacas J. G. (1988) Characteristics of carbonate source rocks of petroleum. In Petroleum Systems of the United States (Ed. Magoon L. B.). U.S. Geol. Surv. Bull. 1870, 20-25.

Peters K. E. and Moldowan J. M. (1993) The Biomarker guide. Interpreting molecular fossils in petroleum and ancient sediments. Prentice-Hall, London.

Peakman T.M., Ellis K. and Maxwell J. R. (1988) Acid-catalysed rearrangements of steroid alkenes. Part 2. A re-investigation of the backbone rearrangement of cholest-5-ene. J. Chem. Soc. Perkin Trans I, 1071-1075.

Peakman T. M., Farrimond P., Brassell S. C. and Maxwell J. R. (1986) De-A-steroids in immature marine shales. Org. Geochem. 10, 779-789.

Peakman T. M., Lamb N. A. and Maxwell J. R. (1984) Naturally occurring spiro steroid hydrocarbons. Tetrahedron Lett. 25, 349-352. 
Peakman T. M. and Maxwell J. R. (1988) Acid-catalysed rearrangements of steroid alkenes. Part 1. Rearrangement of 5 $\alpha$-Cholest-7-ene. J. Chem. Soc. Perkin Trans I, 1065-1070.

Radke M., Garrigues P. and Willsch H. (1990) Methylated dicyclic and tricyclic aromatic hydrocarbons in crude oils from the Handil field, Indonesia. Org. Geochem. 15, 17-34.

Radke M. and Welte D. H. (1983) The methylphenanthrene index (MPI): a maturity parameter based on aromatic hydrocarbons. In Advances in Organic Geochemistry 1981 (Ed. Bjorøy M. et al.), pp. 504-512. Wiley, Chichester.

Radke M., Willsch H. and Welte D. H. (1984) Class separation of aromatic compounds in rock extracts and fossil fuels by liquid chromatography. Anal. Chem. 56, 2538-2546.

Rieley G., Collier R. J., Jones D. M. and Eglinton G. (1991) The biogeochemistry of Ellesmere Lake, U.K. I: source correlation of leaf wax inputs to the sedimentary lipid record. Org. Geochem. 17, 901-912.

Riolo J., Hussler G., Albrecht P. and Connan J. (1986) Distribution of aromatic steroids in geological samples: their evaluation as geochemical parameters. In Advances in Organic Geochemistry 1985 (Edited by Leythaeuser D. and Rullkötter J.), Org. Geochem. 10, 981-990.

Robinson W. E. (1969) Isolation procedures for kerogens and associated soluble organic materials. In Organic Geochemistry, Methods and Results (Ed. Eglinton G. and Murphy M. T. S.), pp. 181-195. Springer, Berlin.

Rubinstein I. and Albrecht P. (1975) The Occurrence of nuclear methylated steranes in a shale. J. Chem. Soc., Chem. Commun. 957-958.

Rubinstein I., Sieskind O. and Albrecht P. (1975) Rearranged sterenes in a shale: occurrence and simulated formation. J. Chem. Soc. Perkin Trans I, 1833-1836.

Sackett W. M. (1978) Carbon and hydrogen isotope effects during the thermocatalytic production of hydrocarbons in laboratory simulation experiments. Geochim. Cosmochim. Acta 42, 571-580.

Seifert W. K. (1978) Steranes and terpanes in kerogen pyrolysis for correlation of oils and source rocks. Geochim. Cosmochim. Acta 42, 473-484.

Seifert W. K. and Moldowan J. M. (1978) Applications of steranes, terpanes and monoaromatics to the maturation, migration and source of crude oils. Geochim. Cosmochim. Acta 42, 77-95.

Seifert W. K. and Moldowan J. M. (1979) The effect of biodegradation on steranes and terpanes in crude oils. Geochim. Cosmochim. Acta 43, 111-126.

Seifert W. K. and Moldowan J. M. (1981) Paleoreconstruction by biological markers. Geochim. Cosmochim. Acta 45, 783-794.

Sieskind O. and Albrecht P. (1985) Efficient synthesis of rearranged Cholest-13(17)-enes catalysed by montmorillonite-clay. Tetrahedron Lett. 26, 2135-2136.

Sieskind O., Kintzinger J. P., Metz B. and Albrecht P. (1991) Structural elucidation of diacholestanes. In Organic Geochemistry. Advances and applications in energy and the natural environment (Ed. Manning D. A. C.), pp. 206-207. Manchester University Press, Manchester.

Steen A. (1986) Gas chromatographic/mass spectrometric analysis (GC/MS) of $\mathrm{C}_{27-30^{-}}$ steranes. In Advances in Organic Geochemistry 1985 (ed. Leythaeuser D. and Rullkötter J.). Org. Geochem. 10, 1137-1142. Pergamon Press, Oxford. 
Summons R. E. and Capon R. J. (1988) Fossil steranes with unprecedented methylation in ringA. Geochim. Cosmochim. Acta 52, 2733-2736.

Summons R. E. and Capon R. J. (1991) Identification and significance of $3 \beta$-ethyl steranes in sediments and petroleum. Geochim. Cosmochim. Acta 55, 2391-2395.

Tissot (1987) Discussion during a seminar at the French Petroleum Institute.

Tissot B., Califet-Debyser Y., Deroo G. and Oudin J. L. (1971) Origin and evolution of hydrocarbons in early Toarcian shales, Paris basin, France. AAPG Bull. 55, 2177-2193.

Tissot B., Durand B., Espitalié J. and Combaz A. (1974) Influence of nature and diagenesis of organic matter in formation of petroleum. AAPG Bull. 58, 499-506.

Tissot B. and Welte D. H. (1984) Petroleum formation and occurrence. 2nd edn. Springer, Berlin.

Wachter E. A. and Hayes J. M. (1985) Exchange of oxygen isotopes and carbon isotopes in carbon dioxide-phosphoric acid systems. Chem. Geol. (Isot. Geosci.) 52, 365-374.

Waples D. W. and Tornheim L. (1978) Mathematical models for petroleum-forming processes: carbon isotope fractionation. Geochim. Cosmochim. Acta 42, 467-472.

Welte D. H. (1969) ${ }^{13} \mathrm{C} /{ }^{12} \mathrm{C}$ Isotope ratios of individual $n$-parafins and the implication to their origin. Naturwissenschaften 56, 133-134.

Welte D. H., Hagemann H. W., Hollerbach A. and Leythaeuser D. (1975) Correlation between petroleum and source rock. $9^{\text {th }}$ World Petr. Congr., 2, 179-191.

Williams J. A. (1974) Characterization of oil types in Williston basin. AAPG Bull. 58, 1243-1252.

Winters K., Parker P. L. and Van Baalen C. (1969) Hydrocarbons of blue-green algae: geochemical significance. Science 163, 467-468. 